cestors of Pty. Mortoni, from the American Greensand, may be represented in time by some of the species of Acrodus, we would invite comparison with an unnamed tooth of this genus from the Forest marble of Stanton, in Wiltshire. In the same way, if the development theory be correct, the connecting links might be hereafter discovered between the more primitive Orodus ramosus of the Carboniferous limestone and the Forest Marble species of Acrodus, and the Acrodus Anningice of the Lias of Lyme Regis.

\title{
NOTES ON THE EVIDENCE OF GLACIAL ACTION IN SCOTLAND.
}

By P. Simmons, Esq., of Whiteinch.

In the parish of Baldernock, county of Stirling, and in the neigh. bourbood of "fragments of stone reared by creatures of clay," Craigmadden Castle, the pedestrian will find three large stones well worthy of his notice. They are situated in the centre of a bog; consequently, if the said pedestrian desires to observe, measure, and minutely examine them, he must, as three friends lately did, take off boots and stockings and wade through the water that surrounds the stones to within two feet; that is to say, if he desires such articles to remain dry. The bog forms part of an extensive natural amphitheatre, situated in the Craigmadden moor; and the stones have received the name " Auld Wives' Lifts," from the

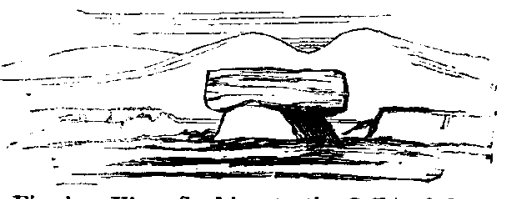

Fig. 1.-View (looking to the S.E.) of the "Auld Wives' Lifts." absurd tradition that they were placed, once upon a time, among the heather by three old women, uatives of Baldernock, Strathblane, and Campsie.

The Lifts are considered by some antiquaries to be nothing more or less than a cromlech or sepulchral monument; others, however, think they are an altar which the Druids used. The former opinion is maintained by Dr. Daniel Wilson in his "Archæology." His words are: "It is remarkable as an example of a trilith, or complete cromlech, consisting only of three stones. Two, of nearly equal length, support the huge capstone; a block of basalt measuring fully 18 feet in length, by 11 in breadth, and 7 in depth. A narrow triangular space remains open between the three stones, and through this every stranger is required to pass on first visiting the spot, if, according to the rustic creed, he would escape the calamity of dying childless. It is not unworthy of being noted, that though the site of this singular cromlech is at no great elevation, a spectator standing on it can see across the island from sea to sea; and may almost at 
the same moment observe the smoke from one steamer entering the Frith of Clyde, and from another below Grangemouth, in the Forth." The view engraved by Dr. Wilson is from the south-east; and, according to his measurement, the weight of the large sandstone, not basalt, capstone is 96 tons; being 46 tons more than a different result of the measuring, which makes the weight 50 tons. The two fragments of sandstone on which this large piece rests are prismatic in shape, lying side by side, forming a triangular opening, which enables any one to creep through. The sketch of the stones as seen from the south-west, gives the reader an idea of the size of this space. In the appendix, No. 4, to Mr. Smith's recently published 'Researches in Newer Pliocene Geology,' Mr. Buchauan considers the Lifts "a very interesting and well-preserved memorial of the remote pagan people of the canoe period," and, like Nilsson, states $=-1$ that " the uppermost is an enormous block of basalt." This mistake causes one to imagine that the stunes have not been properly examined by the said antiquaries. The Lifts are covered with the marks made Tig. 2.-End view by visitors and others. Their position according to of the "Lifts." the compass may be useful, and is consequently here

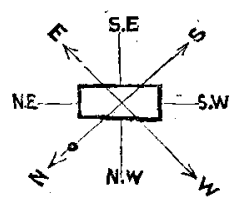
given, as taken from the capstone.

The science of geology enables the unprejudiced observer to declare with boldness, and to prove beyond doubt, that the Auld Wives' Lifts were never placed where they now are by demons, angels, witches, or mortals, of any age. Although, to quote

Fig. 3.-The bear- Kent's well-known lines,ings of the "Lifts."

\footnotetext{
"There's a pleasure on the heath

Where Druids old have been,

Where mantles grey have rustled by

And swept the nettles green,"
}

yet science compels us to give to water and ice the honour of causing the three stones to remain where they now are. T'hey are erratics. This fact, for the evidence is almost demonstrative, is asserted by one

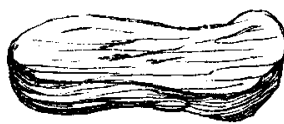
who has made frequent visits to the stones, and a careful examination of the strata in their neighbourhood. The former are angular; " the erratic blocks," Agassiz asserts, " in Switzerland Fig. 4.- Sandstone block, are always angular ;" the latter is composed of S.E. of the "Lifts." sandstone and conglomerate or pudding-stone. The sandstone is both polished and grooved, frequently cut and excavated by some force, doubtless ice. The ice appears to have been aided by a current, which, sweeping along, made the sandstone yield. This ice current appears to have cut the sandstone fragment lying ou the margin of the bog to the south-east of the Lifts.

The stones have been floated to their present position by ice, at a time when the land was depressed by some earthquake movement. "We have," says Mr. Smith, of Jordanhill, in his most interesting 'Researches,' "in the superticial beds in the basin of the Clyde, 
eridences of such a movement, which must have taken place in the period when the climate was colder than at present, and which, if not paroxysmal, was sufficiently rapid to have entombed alive the testaceous inhabitants of the sea, and to have covered them up to a considerable depth with beds of finely laminated clay, which could only have been formed at the bottom of the sea." The current or rush of water made the ice bearing the erraties cut and polish the sandstone in the neighbourhood. This rush of water was doubtless produced by one of those earthquake waves thus described by Mr. Snith in the above-mentioned work, and considered by him to be the force that originated the till or boulder clay:- "A rush of water, such as that produced by earthquake waves, of sufficient violence to tear up, not only the pre-existing unconsolidated cover, but considerable portions of the subjacent rocks, and perhaps obliterate the inequalities caused by disturbances in the coal measures, passed over the island from west to east, or, rather, from the north-west, depositing the - whole in a confused mass on the surface. In that part which was under the sea, beds of gravel, sand, and clay were deposited. In process of time, a second débâcle swept over the island in the same direction, but with much less violence than the first; the stratified beds, perhaps of no great thickness, were swept away, leaving, however, occasional patches sufficient to attest their existence, and also part of the pre-existing diluvium, reducing the inequalities and grinding the exposed surfaces of the rocks and boulders, for it is to this second débâcle I ascribe the scratching of the rocks and boulders; and here, I think, ice acted an important part, and was probably the principal agent in grinding down the substance over which it passed. A colder climate and a north-west direction both point to a frozen ocean, which was perbaps broken up by the convulsion which caused the diluvial wave, and the ice of which was swept over the land in the same direction." Antiquaries formerly imagined the erratics, or the boulders termed rocking stones, to be the workmanship of human hands; now however, Mr. Wright, one of the most talented of their number, asserts that they are the result of natural causes. Geology has proved this; and the same science has also taken from the territory of archæology some of the stones said to be complete cromlechs, the Lifts being an instance.

When examining the boulders near Loch Ken in Kircudbrightshire, I observed among many of great size and gigantic in composition, one 10 feet in height, and 13 feet 9 inches long, resting on two small boulders, prismatic in form. (See sketch.) Workmen were blast-

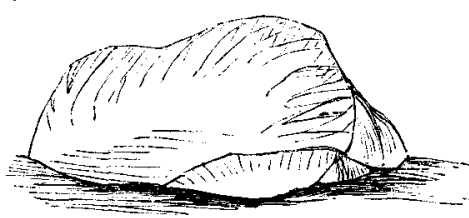

Fig. 5.-Boulder near Loch Ken. ing some of the boulders when I was measuring, consequently their number is decreasing; and the evidence of glacial action in the neighbourhood of Loch Ken, as far as boulders are concerned, will soon cease to exist. This, however, cannot be said of the striking glacial action 
observed on the banks of Loch Doon, in Ayrshire, as the remarkable striated trap-rocks cannot be so easily removed. The openings or striæ are generally narrow, long, and deep; sometimes prismatic. They appear to resemble in sharpness the scratchings considered, by Dr. John Tyndall, in his published 'Description of the Glaciers of

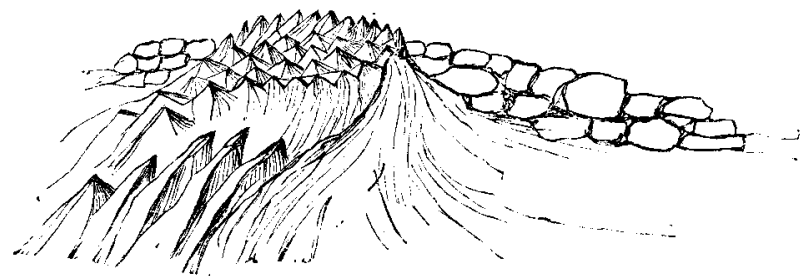

Fig. 6.-Striated basalt, Loch Doon (as seen from the Lake).

the Alps,' to be caused, on the Riffelhorn, by the Görner glacier of former ages. The boulders on the shores of Loch Doon are frequently very large, and mostly basalt; and so numerous, as to constitute entirely the west side of the loch, the waters of which appear to rest on a bed of boulders, four of which are so large as to appear above the surface, and now remain islands. (See sketch.) None of the numerous

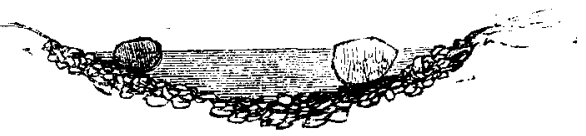
boulders examined by me possess the strong and varied polarity which Dr. Tyndall found to exist in some cast down from the summit of the Riffelhorn. It is not maintained that the many trap-boulders scattered through Scotland were never magnetic; and it is only affirmed that no fragment has yet been discovered that was observed to act forcibly upon a magnetic needle. It may be here remarked, that many of the "jutting prominences" of Dumbarton basalt rock, on which the fortress is situated, like those of the Riffelhorn and Görner Grat, described by Dr. Tyndall, possess the magnetic action caused by the magnetic oxide of iron. Has this magnetism been developed by glacial action?-is a question which cannot be here answered, although it is one worthy of being considered by geologists. The top and base of Dumbarton Rock 1 have examined with a small compass. Near the summit of the portion of this rock called the beacon-tower, the polarity changed, the pole affected being the south, at the distance of 34 inches. In no instance did I observe the compass to be affected in the east portion of the rock, either at the top or base; the reverse was the case with the west portion, both at the top and base, the immense fragments, undoubtedly portions of the rock, removed probably, by lightning, on the terrace at the foot of this part of the rock, being no exception to the "strong and varied polarity."

Glacier pressure is considered by Dr. Tyndall to cause the crust 
observed on trap, or rather the species of trap termed basalt. In the 143rd page of his 'Glaciers of the Alps,' be says, in describing the lower spur of the Riffelhorn: "Midway down the spur I lighted upon a transverse wall of rock, which formed in earlier ages the boundary of a lateral outlet of the Görner glacier. It was red and hard, weathered rough at some places, and polished smooth at others. The lines were drawn finely upon it, but its outer surface appeared to be peeling off like a crust; the polished layer rested upon the rock like a kind of enamel. The action of the glacier appeared to resemble that of the break of a locomotive upon rails; both being cases of exfoliation brought about by pressure and friction." 'This crust is observed on basalt boulders taken out of semicircular mounds, probably caused by glacial action; portions of the crust can easily be removed. My illustrious and valued friend-Mr. James Napier, F.C.S., in his valuable "Remarks on Mineral Veins and Waterworn Stones," read before, and published in the Transactions of the Philosophical Society of Glasgow, March 3rd, 1852, has proved, beyond doubt, that this crust is not the result of pressure but of water. This eminent chemist maintains that water, in contact with and passing through rocks, changes their character, by dissolving out some of their component minerals. The following extract, although long, I cannot refrain from giving, as it clearly explains how the remarkable crust found to exist on trap or basalt rocks originates :"A piece of trap rock, e.g., exposed to water, very soon changes, when alternately wet and dry, and exposed to the atmosphere; the decomposition is sensibly apparent, a brown crust is soon formed, which becomes soft and brittle, breaking off by slight friction, leaving a new portion of the stone to undergo the same change. The same sort of stone embedded in the gravel under the soil, passes through the same changes, but the crust in this case is not so soft and brittle ; the change soon penetrates to the centre of the stone, giving it a different character and appearance." I lately removed portions of the crust from such boulders, taken from a railway cutting in this neighbourhood, almost half an inch thick, and about 12 inches by 6 . Much larger fragments could easily be obtained. "Analysis," continues Mr. Napier, "of the stone so changed, compared with the original, makes the change very apparent. We give the average of many analyses from different localities :-

Kernel, or original stone.

Insoluble silicate of alumina 66.8

Protoxide of iron .. $18 \cdot 5 \mathrm{Fe} 14 \cdot 4$

Lime . . . . . 3.8

Magnesia : . . . . 1.5

Potash . . . . . $2 \cdot 6$

Loss at red heat, water. $.6 \cdot 2$

$99 \cdot 4$
Crust, or altered stone.

Insoluble matter . . . . 72:5

Peroxide of iron . . . $19 \cdot 7 \mathrm{Fe} 13.8$

Lime . . . . . . 0.9

Magnesia . . . . 0.3

Potash . . . . . . . trace

Loss at red heat . . . . $5 \cdot 1$

$99 \cdot 2$

"Here, then, we find that water has dissolved out lime, iron, 
magnesia, and potash, and the remaining iron changed to the peroxide state. The length of time required for the water to penetrate a piece of trap I know not; but that the soluble power of the water is great, is evident, by placing a piece of such rock in distilled water ; 100 grains digested for six days, at summer heat, lost one per cent. : the water had an alkaline reaction, and contained magnesia, potash, and lime." Mr. Napier exhibited a specimen of a boulder, showing "the powerful action constantly going on in the earth, changing the character of rocks;" and he also remarks, that "the crust or outer portion of stones of this soil have generally been looked upon as incrustations, from the water in which they have been placed having salts in solution that have become deposited upon the stone or kernel portion. Such incrustation does take place upon organic substances placed in mineral waters; but in this instance, as in most other minerals, the change has evidently been caused by the decomposition of the original stone."

Not far from the town of Lochwinnoch, on the road to Kilbarchan, in which parish it is situated, stands one of the most remarkable erratics in the west of Scotland. Mr. William Fulton, M.A., Govan, first informed me of its existence, and last July both of us measured it. 'The immense basalt fragment, judging from the direction of the deep and broad scratches on its south-east side, appears to have been

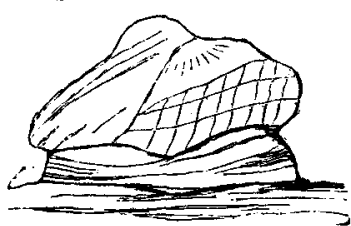

Fig. 8.-Erratic block, Lochwinnoch. carried along in two directions; the force, either ice or running water, thus causing the marks or scratches to cross one another almost at right angles. (See sketch.) The stone is 11 feet in beight and about 69 feet in circumference, and appears to be two miles west of the town of Kilbarchan. The stream called St. Bride's Burn is not very far from the erratic, which receives the local name Clochodrickstone, said to be from the Gaelic, meaning the Druid's stone.

\section{AN ATTEMPT TO CORRELATE THE GLACIAL AND POST-GLACIAL DEPOSITS OF THE BRITISH ISLES, AND TO DETERMINE THEIR ORDER OF SUCCES- SION.}

\section{By Professor Winliam Kina,}

Of the Queen's University, Ireland, and the Queen's College, Galway.

The classification given in the sequel is based on the following premises :-

1st. The entire area of the British Isles has undergone at different times, during the Glacial and Post-Glacial periods, a succession of secular elevating and subsiding movements.

2nd. At the close of the Pliocene period, the relative level of land 